Research Article

\title{
Identifying maize yield and precipitation gaps in Uganda
}

\author{
Terence Epule Epule ${ }^{1,2} \mathbb{D} \cdot$ Driss Dhiba $^{1} \cdot$ Daniel Etongo $^{3} \cdot$ Changhui Peng $^{4} \cdot$ Laurent Lepage $^{4}$
}

Received: 23 December 2020 / Accepted: 23 March 2021 / Published online: 7 April 2021

(C) The Author(s) 2021 OPEN

\begin{abstract}
In sub-Saharan Africa (SSA), precipitation is an important driver of agricultural production. In Uganda, maize production is essentially rain-fed. However, due to changes in climate, projected maize yield targets have not often been met as actual observed maize yields are often below simulated/projected yields. This outcome has often been attributed to parallel gaps in precipitation. This study aims at identifying maize yield and precipitation gaps in Uganda for the period 1998-2017. Time series historical actual observed maize yield data (hg/ha/year) for the period 1998-2017 were collected from FAOSTAT. Actual observed maize growing season precipitation data were also collected from the climate portal of World Bank Group for the period 1998-2017. The simulated or projected maize yield data and the simulated or projected growing season precipitation data were simulated using a simple linear regression approach. The actual maize yield and actual growing season precipitation data were now compared with the simulated maize yield data and simulated growing season precipitation to establish the yield gaps. The results show that three key periods of maize yield gaps were observed (period one: 1998, period two: 2004-2007 and period three: 2015-2017) with parallel precipitation gaps. However, in the entire series (1998-2017), the years 2008-2009 had no yield gaps yet, precipitation gaps were observed. This implies that precipitation is not the only driver of maize yields in Uganda. In fact, this is supported by a low correlation between precipitation gaps and maize yield gaps of about $6.3 \%$. For a better understanding of cropping systems in SSA, other potential drivers of maize yield gaps in Uganda such as soils, farm inputs, crop pests and diseases, high yielding varieties, literacy, and poverty levels should be considered.
\end{abstract}

\section{Article Highlights}

- When actual maize yields are less than simulated maize yields, maize yield gaps are said to exist

- Precipitation gaps occur when actual precipitation is below simulated precipitation

- Maize yields are driven by precipitation and other variables like soils and socio-economic circumstances

Keywords Maize - Yield gaps · Precipitation gaps - Literacy rates - Poverty rates - Farm inputs - Crop pests and diseases . High yielding varieties $\cdot$ Uganda

$\triangle$ Terence Epule Epule, epule.terence@um6p.ma; terence.epule@mail.mcgill.ca| ${ }^{1}$ International Water Research Institute, Mohammed VI University Polytechnic, Lot 660, Hay Moulay Rachid, 43150 Ben Guerir, Morocco. ${ }^{2}$ Department of Geography, McGill University, 805 Sherbrooke St. West. Burnside Hall 416, 4, Montreal, QC H3A 0B9, Canada. ${ }^{3}$ Department of Environmental Sciences, University of Seychelles, Anse Royale, Seychelles. ${ }^{4}$ University of Quebec at Montreal (UQAM), Succ Centre-Ville, Case postale 8888, Montreal, QC H3C 3P8, Canada. 


\section{Introduction}

Globally, agricultural production needs to be increased by $70-100 \%$ by 2050 to ensure that a global population of over 9 billion can be fed [14]. It has been projected that a global decline in annual growth of food production from about 2.2 to $1.1 \%$ is likely to occur for the period 2006-2050 [6]. In Africa, the annual growth rate is projected to decline from 3.0 to $2.1 \%$ for the period 2006-2050 [6]. The repercussions of this decline are likely to be more daunting as agricultural production is essentially carried out by small-scale peasant farmers who constitute about $70 \%$ of the farming population. There are enormous difficulties associated with producing food under such constrained conditions. Small-scale farmers are less capable of coping with complex multi-level climatic and socio-economic constraints that have implications on food production. The challenge of coping with the twin constraints of climatic and socio-economic constraints is further compounded by global environmental changes that affect crop production. Some of these constraints are yield and precipitation gaps, driven by precipitation, degraded soils, lack of access to farm inputs, and crop pests and diseases $[5,51,53,62]$.

Agriculture is the "life wire" or "backbone" of the Ugandan economy. This assertion is true as agriculture accounts for about $20 \%$ of the country's gross domestic product (GDP) and about $48 \%$ of export earnings [34]. In Uganda, agriculture employs more than $70 \%$ of the population and about 4 million people depend on small-scale farming for their sustenance [34]. It has also been stated that, in Uganda, poverty reduction is contingent on developments in agriculture [30, 34, 49]. This is made difficult as Ugandan cropping systems are susceptible to climatic conditions. This is seen as major droughts in the last decade had significant impacts on yields and crop prices in 2006. The effects of the 2010 and 2011 droughts led to deficits of 2.8 trillion $\left(2.8 \times 10^{12}\right)$ Uganda shillings; an equivalent of US\$ 1.2 billion (US\$1.2 $\times 10^{9}$ ); $7 \%$ of Uganda's GDP [13].

In the peer review scholarship, a lot of emphasis has not been placed on maize yield gaps in Uganda. The only studies that have come close to handling yield gaps at the level of Uganda are: Wang et al. [64] dwelling on coffee yield gaps and Mugisha et al. [44] focusing on yield gaps in groundnuts using a gender-based perspective. Also, Senthilkumar et al. [57] dwelled on rice yield gaps in eastern and southern Africa. Other studies have focused on the magnitude of precipitation deficits and temperature changes, [41, 42]. Within this context, and in view of the importance of maize in Uganda an analysis of maize yield gaps in Uganda is novel and original as this has not been done before. This study therefore contributes to the scholarship in yield gaps and is a pioneer in maize yield gaps in Uganda. It has been argued that the effects of precipitation gaps on crops yields may depend on the adaptive capacity of the farmers [59]. In the face of very huge precipitation gaps, the effects might be determined by the ability of the farmers to adapt, in other words, the socio-economic conditions of the farmers through proxies such as literacy and poverty which may influence adaptive capacity more than just the magnitude of the precipitation gaps [59].

An assessment of the relationship between actual and projected maize yields on the one hand and actual and projected precipitation on the other hand is important for agricultural adaptation [6]. This approach also offers insights into agricultural performance, the potential for yield growth and an opportunity to monitor and anticipate yield gaps. It also heralds an opportunity to explore the role of non-climatic drivers of the observed yield trends and the role of other constraints such as soils and socioeconomic circumstances in narrowing yield gaps. An understanding of the extent to which climatic constraints contribute to explaining the yield gaps can inform adaptation by creating opportunities to verify other non-climatic constraints. When climatic constraints such as precipitation are of less importance in accounting for crop yield gaps, a tilt towards socio-economic drivers is important. The climate of Uganda is diversified, and this offers a huge potential for the development of a wide range of food systems. However, variations in precipitation often lead to yield gaps and this is often confounded by constraints of degraded soils and socio-economic constraints. Within this context, this study considers actual maize yields as the actual observed harvest that the farmers obtain in a year. On the other hand, the projected maize yields represent the simulated, forecasted maize yields for a given year. Actual precipitation on the other hand is the observed precipitation obtained during the maize growing season while projected precipitation is the simulated or forecasted precipitation received during the maize growing season [7].

This study therefore has as primary objectives to (1) identify maize yield and precipitation gaps in Uganda based on time series data for the period 1998-2017 in Uganda and (2) seeks to discuss the role of precipitation and other possible drivers of maize yield gaps as reported in the scientific scholarship. This study is important because it uses maize (Zea mays) as the main crop for analysis for the following reasons: (1) it is among the most widely cultivated crops in the world (maize, wheat, rice, soybeans, barley, sorghum). It is affordable and most widely grown in most African countries and in Uganda [8, $15,38]$. (2) In Uganda, maize is consumed as staple fermented dough, roasted, used as corn porridge, or used as "corn beer." (3) Maize is produced primarily ( 70-90\%) by 
small-scale farmers $[8,16,46,49]$ and (4) Ugandan maize is also grown across the country in differing agro-climatic zones, requiring medium $(500 \mathrm{~mm} /$ growing season month) to high ( $800 \mathrm{~mm} /$ growing season month) precipitation [46]).

\section{Material and methods}

This study is based on time series data of actual observed maize yields (hg/ha/year) and actual observed maize growing season precipitation for Uganda. The maize yield data were obtained from the Food and Agricultural Organization, FAOSTAT [17] website (http://faostat.fao.org). The time series of maize data covered a 20 -year period from 1998 to 2017 during which enough data were available. The actual maize yield data were subjected to detrending by removing a linear model of the time series of the actual observed maize yields by dividing the projected linear trend by the actual linear trend (see Eq. 1). Detrending helps to remove the repercussions of increased technology, illustrates annual maize yield variations as a result of precipitation, and reduces the effects of consistent errors in reporting $[36,37,39]$.

On the other hand, the actual observed time series of average growing season precipitation for Uganda for the period 1998-2017 were generated from climate portal of the World Bank Group [65]. These data were validated by averaging over the maize growing months for each $5^{\prime} \times 5^{\prime}$ grid for Uganda from the Global Crop Calendar Dataset [52]. Rather than use annual averages of precipitation, this study identified and defined the maize growing season precipitation for Uganda (Fig. 1). Spatial variations in the maize growing season exist in Uganda. According to various maize crop calendars [17, 18, 24, 52], the south of Uganda has a bi-modal maize growing season. The first maize growing season begins with sowing in February and March, growing in April and May while harvesting occurs in June and July. The second maize growing season begins with sowing in September and October, growing in November and harvesting in December. The north has a uni-modal (mono-modal) or single growing season. Sowing occurs in April and May, growing in June and July and harvesting in August and September (Fig. 1.).

Projected $_{t y}=a x+b$

where Projected $_{t y}$ is the projected/simulated theoretical maize yield, $\chi$ is the year, $a$ is the linear trend, $b$ is the intercept when Projected $t y=a x$.

To be able to compute maize yield and precipitation gaps and surpluses, projected maize yields and projected growing season precipitation had to be estimated. The projected yields were simulated for each year by using the trend line equation for a simple linear regression (Eq. 2) while the projected growing season precipitation were projected by using the trend line equation for a simple linear regression for growing season precipitation (Eq. 3).The intercepts and slopes or linear trend lines for both maize yield and growing season precipitation were computed using the slope and intercept functions in excel. The slope and intercept are based on the relationship between the actual observed yield, precipitation, and time (Eq. 4 and 5).

Projected $_{y}=536.45 x+14543$

where Projected ${ }_{y}$ is the projected/simulated maize yield, $\chi$ is the year, 536.45 is the linear trend/slope, 14,543 is the intercept when Projected $_{y}=536.45 x$.

Projected $_{p}=-0.0332 x+107.41$

where Projected $_{p}$ is the protected/simulated growing season precipitation, $\chi$ is the year, -0.0332 is the linear trend/ slope, 107.41 is the intercept when Projected $_{p}=-0.0332 x$. Intercept $_{y p}=$ intercept

( time series of yield or ppt: observed yield or ppt)

where Intercept $t_{y p}$ is the intercept of yield and precipitation Slope $_{y p}=$ slope (time series of yield or ppt: observed yield or ppt)

where Slope $e_{y p}$ is the slope of yield and precipitation.

Once the projected yields and growing season precipitation were computed, the resulting outputs were used to compute the yield and precipitation gaps and surpluses for the various years. The gaps and surpluses were based on the differences observed between actual observed yields/ growing season precipitation and projected/simulated yields/growing season precipitation (Eqs. 6 and 7). Based on the use of actual and projected precipitation and yield data in this study, the following hypothesis can be formulated: when actual precipitation and yields are lower than projected precipitation and yields, precipitation and yield gaps are said to occur.

Yieldgaps $_{y s}=$ Actual $_{y}-$ Projected $_{y}$

where Yieldgaps ys $_{\text {represents yield gaps or surplus, Actual }}$ is the actual/observed yields, Projected $_{y}$ is the projected/ simulated yeild

PPTgaps $_{s}=$ Actual $_{p p t}-$ Projected $_{p p t}$

where PPTgaps, represents precipitation gaps or surplus, Actual $_{p p t}$ is the actual/observed precipitation, Projected $_{p p t}$ is the projected/simulated precipitation. 


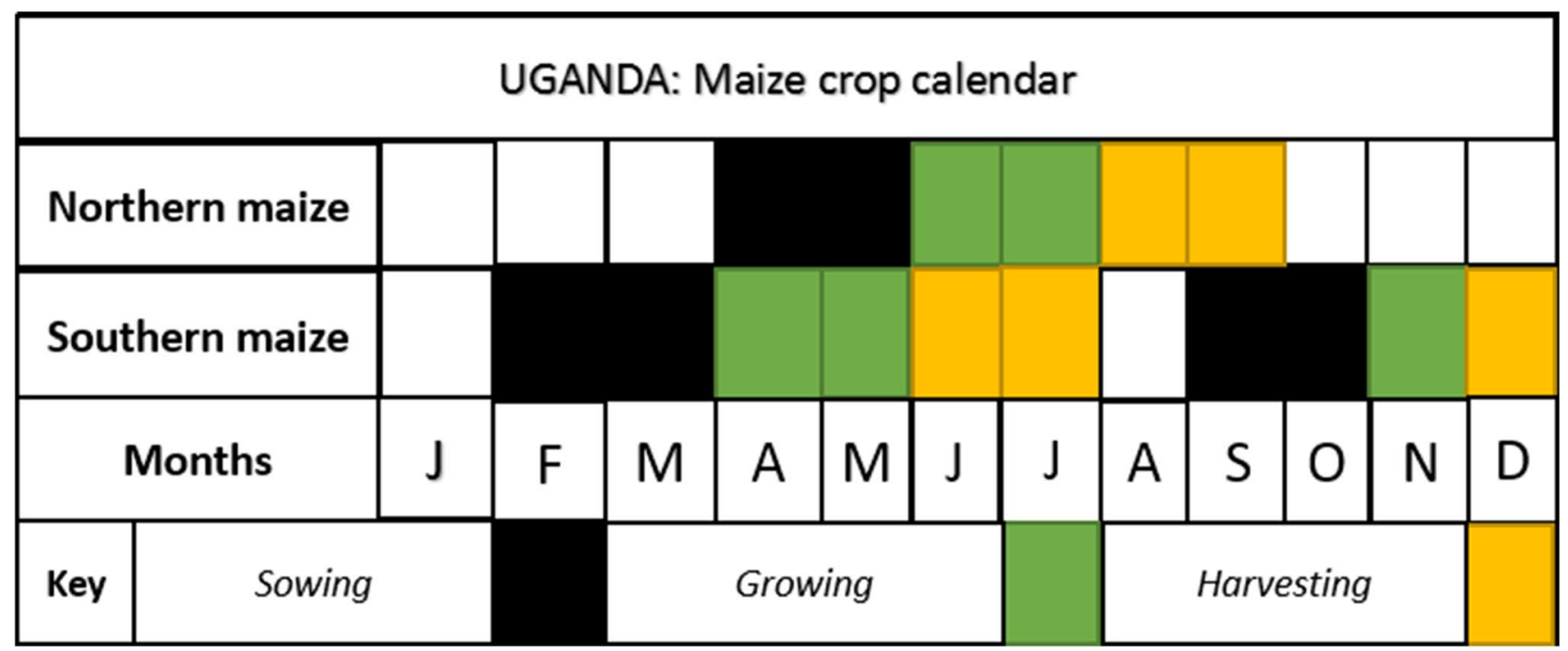

Fig. 1 Maize crop calendar for Uganda. Source: Author's conceptualization inspired from; FAO [18]

\section{Results}

\subsection{Lower actual precipitation over projected precipitation drives precipitation gaps}

The average annual actual growing season precipitation recorded for the period 1998-2017 is $107.06 \mathrm{~mm}$ (Fig. 2). However, the maximum or highest record of average annual actual growing season precipitation for a single year was $147.55 \mathrm{~mm}$; it was recorded in 2010. It can be observed that, the average annual actual growing season precipitation for 2010 of $147.55 \mathrm{~mm}$ is above the average of $107.06 \mathrm{~mm}$ for the period 1998-2017 (Fig. 2). On the other hand, the minimum or lowest record of annual growing season precipitation was $86.46 \mathrm{~mm}$, recorded in 2000. This minimum is below the average for the entire period 1998-2017 and the parallel precipitation gap for that year is $-20.84 \mathrm{~mm}$. In the latter case, the projected is higher than the actual. The maximum actual annual growing season precipitation of $147.55 \mathrm{~mm}$ recorded in 2010 is higher than the projected average annual growing season precipitation of $106.98 \mathrm{~mm}$ recorded for the same year 2010 . Since the actual annual average growing season precipitation for 2010 is higher than the projected, a surplus in precipitation of $40.57 \mathrm{~mm}$ is recorded in 2010 (Fig. 2). Therefore, it has been observed that when the actual average annual growing season precipitation is higher than the projected annual growing season precipitation, a surplus in precipitation is recorded.

Considering the average annual projected growing season precipitation, it is observed that 1998 recorded the maximum average annual projected growing season precipitation of $107.37 \mathrm{~mm}$ (Fig. 2). This is slightly above the average for the 1998-2017 period of $107.06 \mathrm{~mm}$ (Fig. 2). At the maximum projected average annual growing season precipitation level for 1998 is recorded a higher actual average annual growing season precipitation of $116.81 \mathrm{~mm}$ (Fig. 2). The resultant average annual growing season precipitation surplus is $9.42 \mathrm{~mm}$. On the other hand, the lowest or minimum projected annual growing season precipitation was recorded in 2017 at $106.74 \mathrm{~mm}$. This is slightly below the average for the 1998-2017 period but above the actual average annual growing season precipitation of $97.54 \mathrm{~mm}$ (Fig. 2). With the minimum projected average annual growing season precipitation higher than the actual annual growing season precipitation for the same year, a precipitation gap of $-9.20 \mathrm{~mm}$ is recorded.

\subsection{Lower actual yields over projected yields drives maize yield gaps}

In the context of actual yields, an average of $20,175.25 \mathrm{hg} /$ ha (Fig. 3) of maize were recorded for the period 1998-2017. This average is below the maximum or highest of $25,046 \mathrm{hg} / \mathrm{ha}$ (Fig. 3) actual maize yield recorded for 2014. Also, the actual maximum maize yield for 2014 is higher than the projected maize yield of $23,662.16 \mathrm{hg} / \mathrm{ha}$ (Fig. 3) for the same year. When the actual yield is above the projected yield, a surplus of $1383.83 \mathrm{hg} / \mathrm{ha}$ is recorded in 2014. In 2014, the maximum actual yield record of $25,046 \mathrm{hg} / \mathrm{ha}$ (Fig. 3) corresponds to an average growing season precipitation of $95.30 \mathrm{~mm}$. However, the projected yield of $23,662.16 \mathrm{hg} / \mathrm{ha}$ (Fig. 3) for 2014 corresponds to a higher projected average annual growing season precipitation of $106.84 \mathrm{~mm}$. It can be observed here that higher 
levels of average annual growing season precipitation are not always associated to higher maize yields.

When the projected maize yields are considered, it can be observed that the year 2017 recorded the maximum yields of $25,271.5 \mathrm{hg} / \mathrm{ha}$. The latter is higher than the corresponding actual maize yield of $23,177 \mathrm{hg} / \mathrm{ha}$ for 2017. Since the actual maize yield is less than the projected maize yield, a maize yield gap of $-2094.51 \mathrm{hg} / \mathrm{ha}$ is recorded. The higher projected maize yield corresponds to a projected annual growing season precipitation of $106.74 \mathrm{~mm}$ while the lower actual maize yield for that same year has an actual annual growing season precipitation of $97.54 \mathrm{~mm}$. It can be said here that the higher projected yields are parallel to higher growing season precipitation while the actual yields are lower than the projected yields and so is the corresponding precipitation. On the other hand, the minimum or lowest maize yield of $15,078.93 \mathrm{hg} / \mathrm{ha}$ is recorded in 1998 . The corresponding actual maize yield for the same year is lower at $15,000 \mathrm{hg} /$ ha. When projected yields are greater than actual yields, a gap in yields is said to exist and in this case a yield gap of $-78.98 \mathrm{hg} / \mathrm{ha}$ is recorded.

\subsection{Maize growing season precipitation and yield gaps}

These results show that during the period 1998-2017 three major episodes of yield gaps were recorded. During these episodes, projected maize yields were above the actual observed maize yields (Fig. 4a). This was first recorded in 1998 with a yield gap of $-78.98 \mathrm{hg} / \mathrm{ha}$. Though this gap did not have a corresponding precipitation gap, the yield gap observed was marked by the onset of precipitation gaps that began in 1999 and extended into 2000 and 2001. The respective precipitation gaps were $-1.02 \mathrm{~mm}$, $-20.84 \mathrm{~mm}$ and $-14.07 \mathrm{~mm}$ for the years 1999, 2000 and 2001 respectively (Fig. 4b). The second episode of yield gaps was between 2004 and 2007 (Fig. 4a). The yield gaps
Fig. 2 Actual (a), projected (b) average maize growing season precipitation $(\mathrm{mm})$ and $\mathbf{c}$ average growing season precipitation $(\mathrm{mm})$ gaps/surpluses

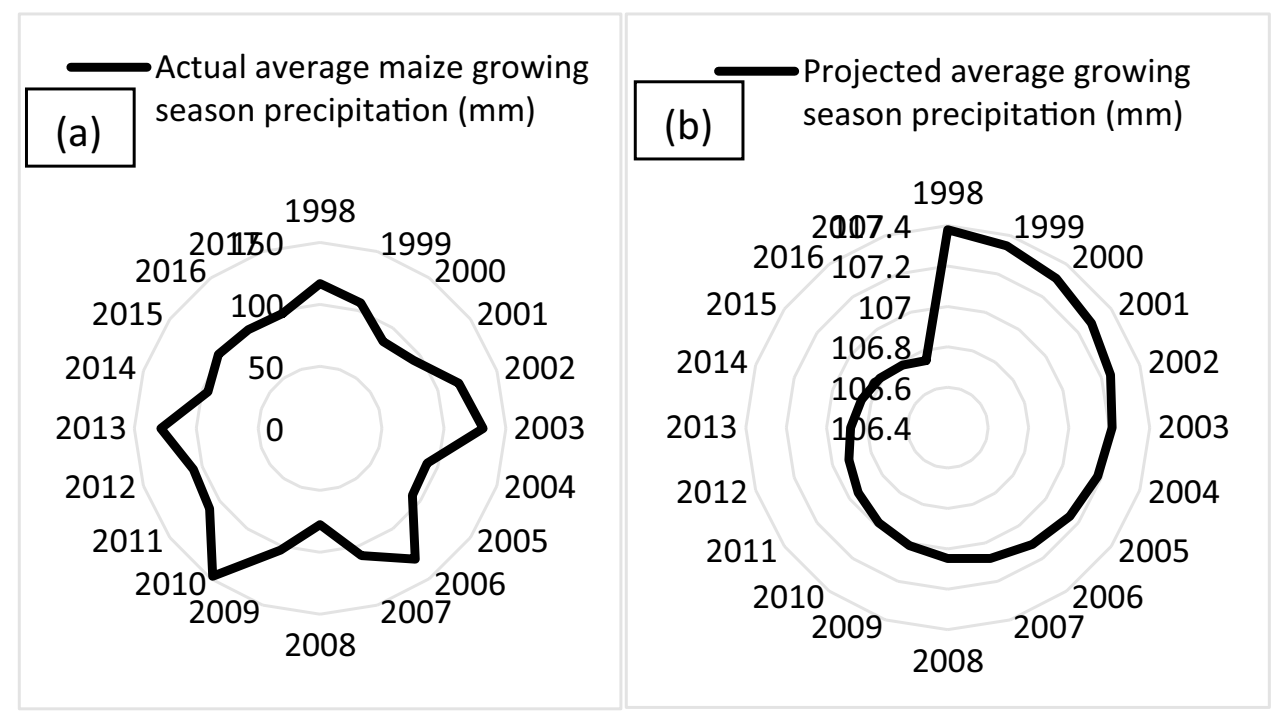

(c) Average growing season precipitation gaps/surpluses ( $\mathrm{mm}$ )

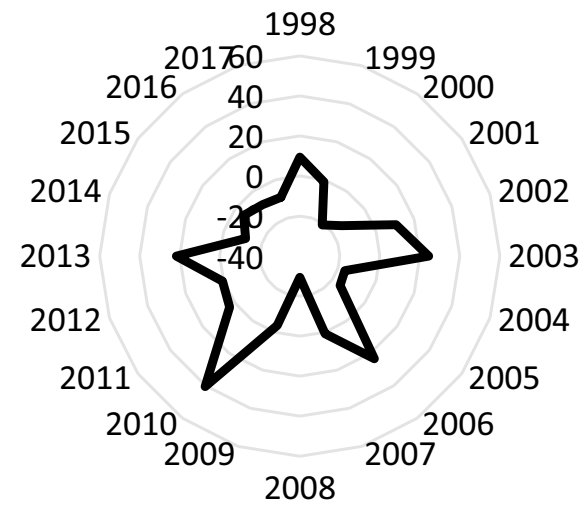


were $-3897.62 \mathrm{hg} / \mathrm{ha}$ in $2004,-2975.13 \mathrm{hg} / \mathrm{ha}$ in 2005 , $-4009.58 \mathrm{hg} / \mathrm{ha}$ in 2006 and $-4957.03 \mathrm{hg} / \mathrm{ha}$ in 2007 (Fig. 4a). Interestingly, this period was also marked by precipitation gaps recorded during the years 2004 and 2005 of $-16.33 \mathrm{~mm}$ and $-15.11 \mathrm{~mm}$ respectively (Fig. $4 \mathrm{~b}$ ). The third period of maize yield gaps was between 2015 and 2017. Here, yield gaps of $-669.61 \mathrm{hg} / \mathrm{ha}$ were observed in 2015, - 1558.07 hg/ha in 2016 and -2094.5 hg/ha in 2017. These years of yield gaps were also parallel to precipitation gaps of $-5.40 \mathrm{~mm},-8.23$ and $-9.20 \mathrm{~mm}$ recorded during the years 2015, 2016 and 2017 respectively (Fig. 4b). From these results, it can be observed that some of the years with maize yield gaps also had parallel precipitation gaps. This implies that maize annual growing season precipitation had a positive relationship with maize yields for some years between 1998 and 2017. The only exception observed from these results was for the years 2008 and 2009 during which there were no maize yield gaps as the actual observed yields were above the projected yields
(Fig. 4a) yet, precipitation gaps were recorded. In this context it can be said that the observed yield trends were not greatly affected by the observed gaps in precipitation. This is supported by a very low correlation between annual growing season precipitation gaps time series and yield gaps time series of 0.063 or about $6.3 \%$. In other words, the precipitation gaps only weakly explain the yield gaps. Therefore, to better explain maize yield gaps, it is essential to integrate non-climatic variables.

These results show that the regression models in Fig. $4 a, b$ fits the observed yield and precipitation data (Figs. 5,6 ). In the context of the relationship between actual and projected yields, the coefficient of determination of 0.62 shows that $62 \%$ of the data fits the regression (Fig. 4a). In other words, this regression is valid and explains about $62 \%$ of the relationship between actual and projected yields. Also, in the context of the relationship between actual and projected precipitation a coefficient of determination of 1 shows that this relationship
Fig. 3 Actual (a), projected (b) maize yield (hg/ha) and c maize yield (hg/ha) gaps/ surpluses

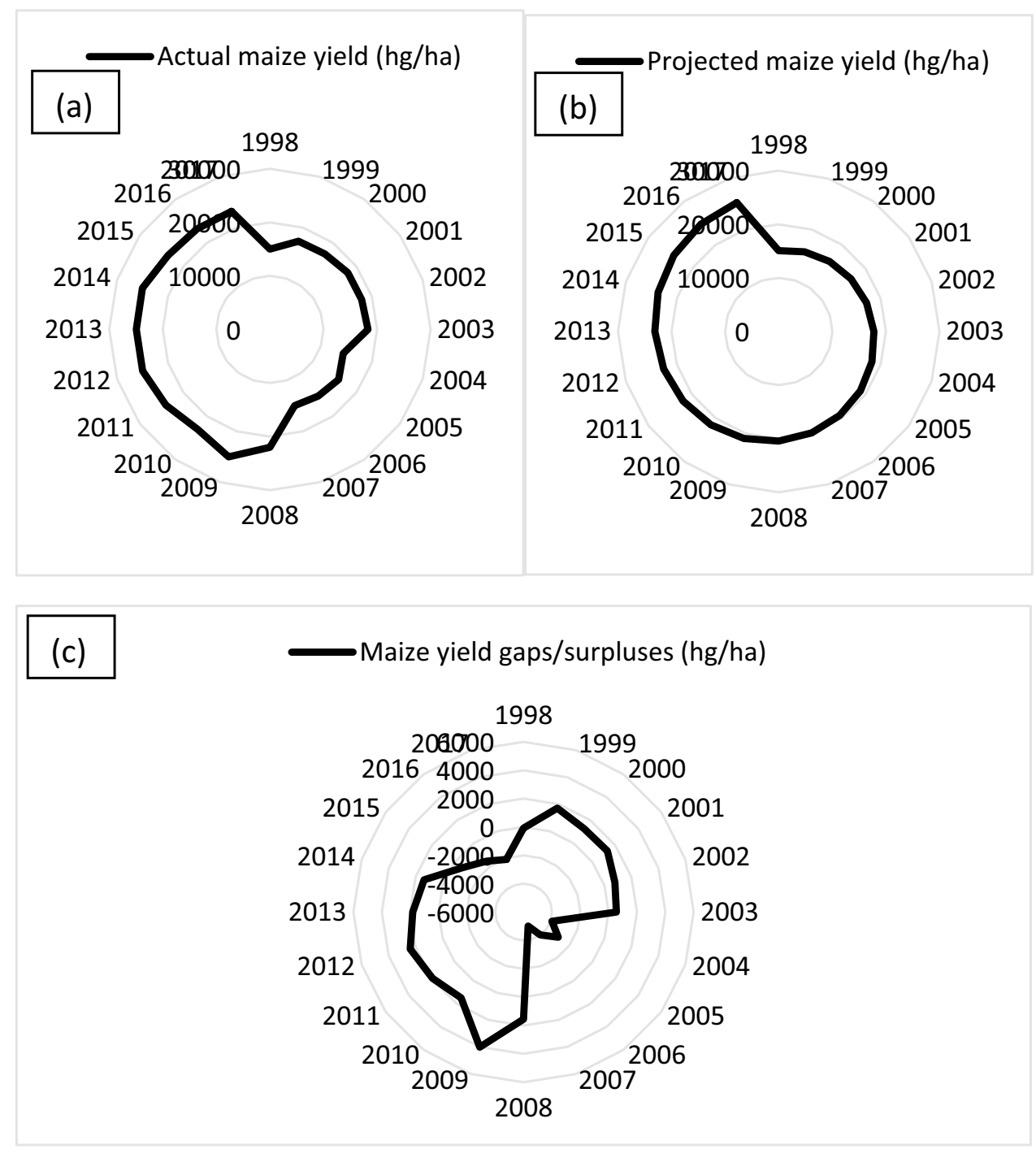


is very strong and explains about $100 \%$ of the relationship between these variables (Fig. 4b). In fact, in 2007, Uganda recorded about $14,000 \mathrm{hg} / \mathrm{ha}$ in maize yields. Thereafter, a period of excess production was noted with $22,000 \mathrm{hg} / \mathrm{ha}$ in 2008 and $24000 \mathrm{hg} / \mathrm{ha}$ in 2009. In the time series since 2007, gaps in yield only set in again around 2015 when projected yields exceeded observed yields (Fig. 5). These increases in production were associated to increase precipitation, high yielding varieties, extension services and limited pest outbreaks. When actual precipitation rises, there is a tendency for actual yields to rise, this is also shown by a coefficient of determination of 0.60 which shows that the regression model fits the observed data and that the observed trends in actual maize yield can be explained by $60 \%$ of the changes in annual growing season precipitation (Fig. 7a). On the other hand, when projected precipitation rises, actual maize yields also initially rise and after a threshold of about $25,000 \mathrm{hg} / \mathrm{ha}$ the more the annual growing season precipitation the more the decline in maize yields (Fig. 7b). This relationship also has a coefficient of determination of about $62 \%$ implying that $62 \%$ of the changes in actual maize yield can be explained by changes in projected annual growing season precipitation.

\section{Discussion}

In Uganda, precipitation plays a role in determining maize yield gaps. Most of the years during which maize yield gaps occurred were associated with parallel gaps in precipitation. This phenomenon is common in most African countries in which agriculture is essentially precipitation dependent or rain-fed $[9,48]$. In Uganda, optimal maize production occurs under precipitation amounts of between 500 and $600 \mathrm{~mm}$ well distributed over the growing season [40]. In this study, it has been observed that most of the maize yields obtained were obtained at sub-optimal level as the actual growing season precipitation amounts were often below the projected amounts. However, with a low correlation of about $6.3 \%$ between annual growing season precipitation gaps and maize yield gaps, it is obvious that many other factors play a role in the total maize yield trends recorded; precipitation simply reinforces an already bad situation. It has already been argued that in most African countries, agriculture is dependent on precipitation and this presents important challenges to farmers $[19,20,31,54,61]$. The situation is even much more daunting as small-scale farmers are responsible for most agricultural production in sub-Saharan Africa (SSA) and are least equipped to

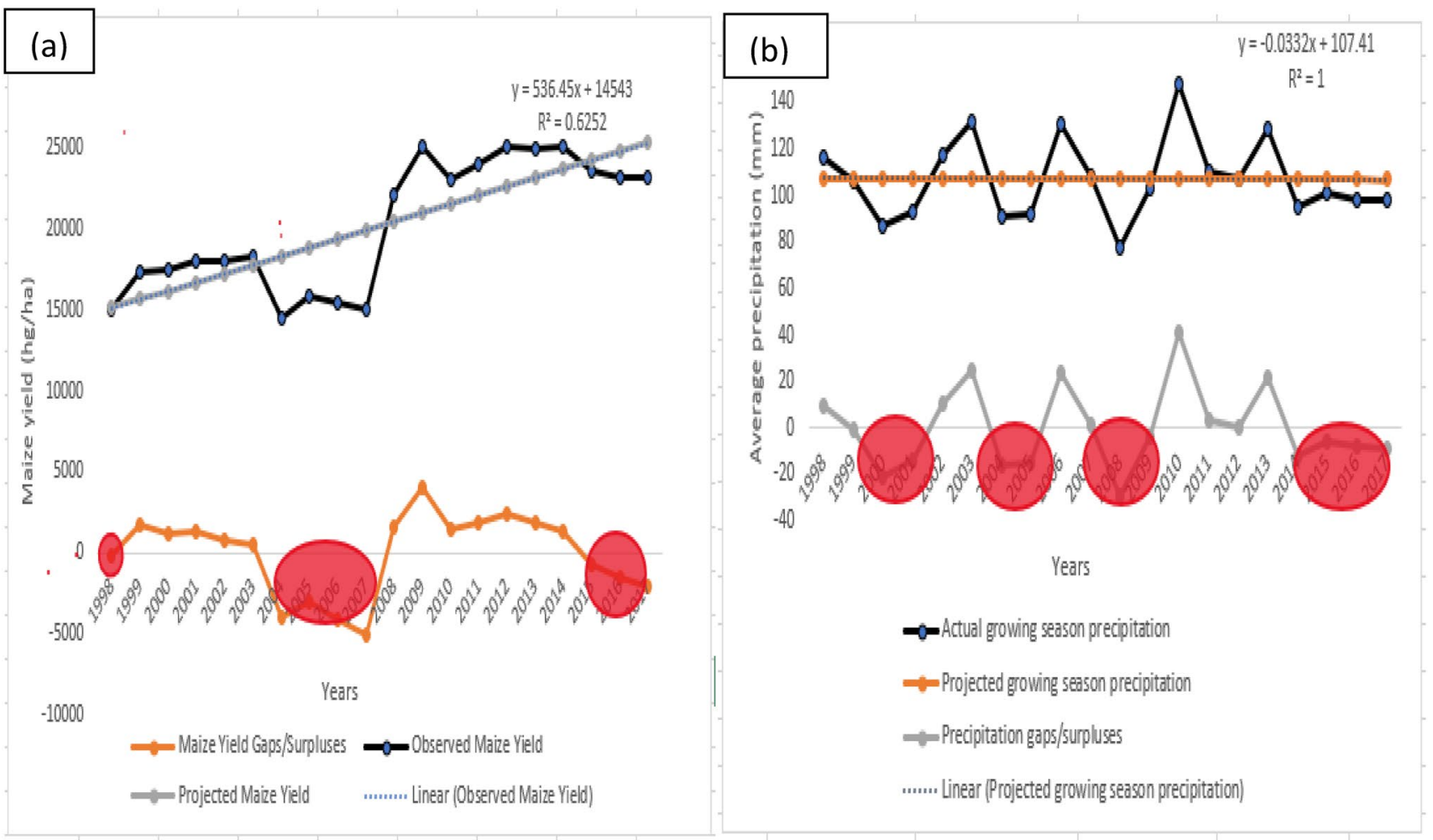

Fig.4 a Time series of projected, actual and yield gaps $\mathbf{b}$ time series of projected, actual and precipitation gaps in Uganda 
adapt $[8,10,45,58]$. The effects of precipitation gaps also reflects the degree of vulnerability of cropping systems $[11,21,22,26,59]$.

The role of annual growing season precipitation in conditioning agricultural production across Africa has been subject to debates and arguments in the scientific literature. This study has shown that precipitation has a limit because as crop yields increase with increase precipitation, beyond a certain threshold maize yields begin to decline even as precipitation increases (Fig. 7b). There is increasing evidence across Africa that supports this premise. For example, based on Normalized Difference Vegetation Index (NDVI) studies over Africa, it has been observed that the Sahel for example is getting greener due to an increase in precipitation after the drought decade of 1975-1985 [29]. If precipitation is currently rising in most of the Sahel, then the big question is, why does the region still experience rife rates in food insecurity and gaps in maize yield and other crops? This invariably heralds the idea that the precipitation gains are not often available for agriculture due to an interplay of other variables that are essentially non-climatic such as poorly distributed precipitation, population growth, systems of land use, high yielding varieties, crop pests and accelerated deforestation $[28,29]$. However, it has also been argued that the notion of increasing precipitation across most of the Sahel for example should be handled with caution as these findings are based on large scale NDVI based studies which might not adequately reflect what obtains at the catchment area scale in individual African countries [9]. Therefore, a need for finer-scale or country level studies to verify this assertion is recommended [25],this current study is one such example.

Understanding maze yield gaps in general heralds the need for verifications beyond climatic variables. Fertile volcanic soils in Western Uganda along Lake Edward can explain the higher maize yields in that region $[33,34]$. The fertile clay soils in the Southwest of the Nebbi district and around Jinja and Central Uganda are also driving crop yields positively [33, 34]. In the "Fertile Crescent" deep red loam soils have also been favorable to crop production in general. Soils are also drivers of yield gaps. For example, patches of infertile soils such as the montane soils around the upper slopes of Mount Elgon and parts of Western Uganda also drive crop yield gaps in Uganda. The Singo Hills north of Lake Wamala in central Uganda are also included. In the northern parts of Uganda, most of the districts ranging from Gulu, Kitgum, to Moroto and most of Kotido, Kumi and Soroti have mostly soils that are shallow, sandy with low productivity and maize yield gaps [33, 34].

Some other factors affecting maize yields in Uganda have been reported in the scientific scholarship and include but not limited to low adoption of improved varieties (genetics), pests and diseases, limited use of inputs and, poor knowledge on crop management and post-harvest management (extension) [35, 47, 60]. The drought periods between 2003 and 2007 were also associated with an outbreak of gray leaf spot disease and stem borers in Uganda. The drought periods between 2015 and 2017 were also associated with an outbreak of maize lethal

\section{0}

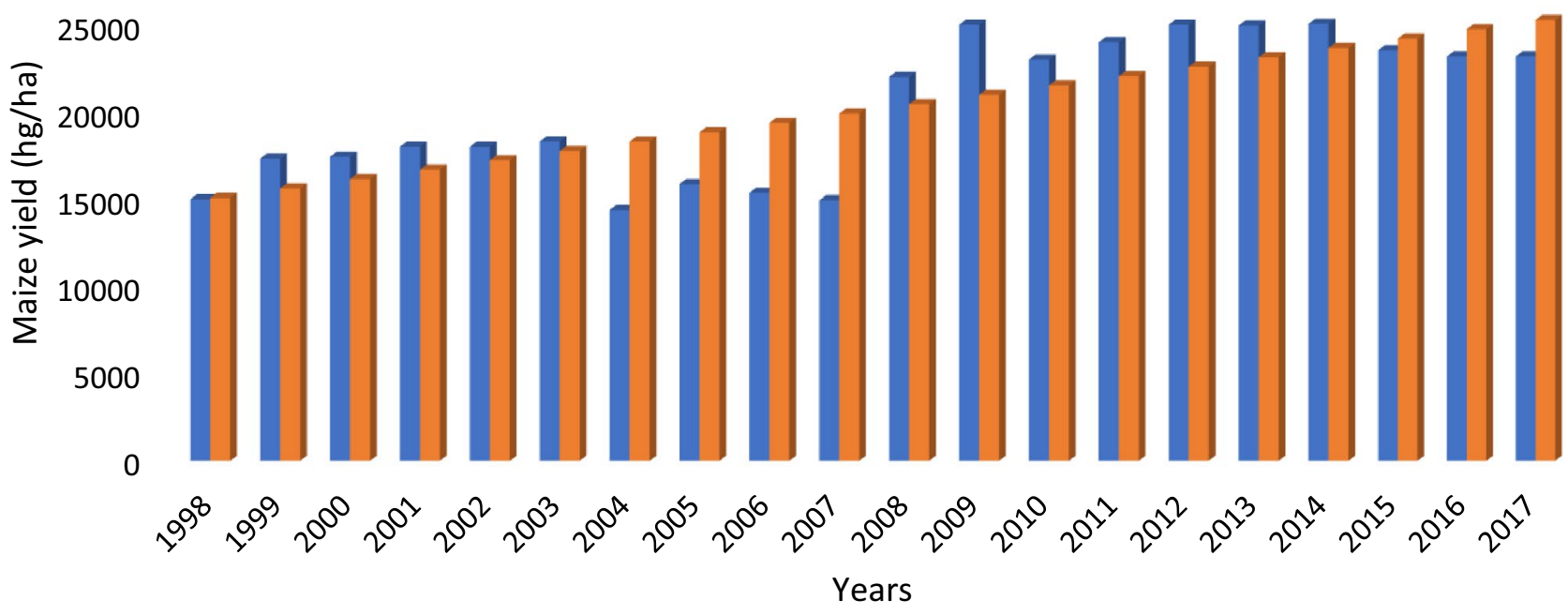

Actual Observed yields $\quad$ Projected yields

Fig. 5 Actual and projected maize yield in Uganda 


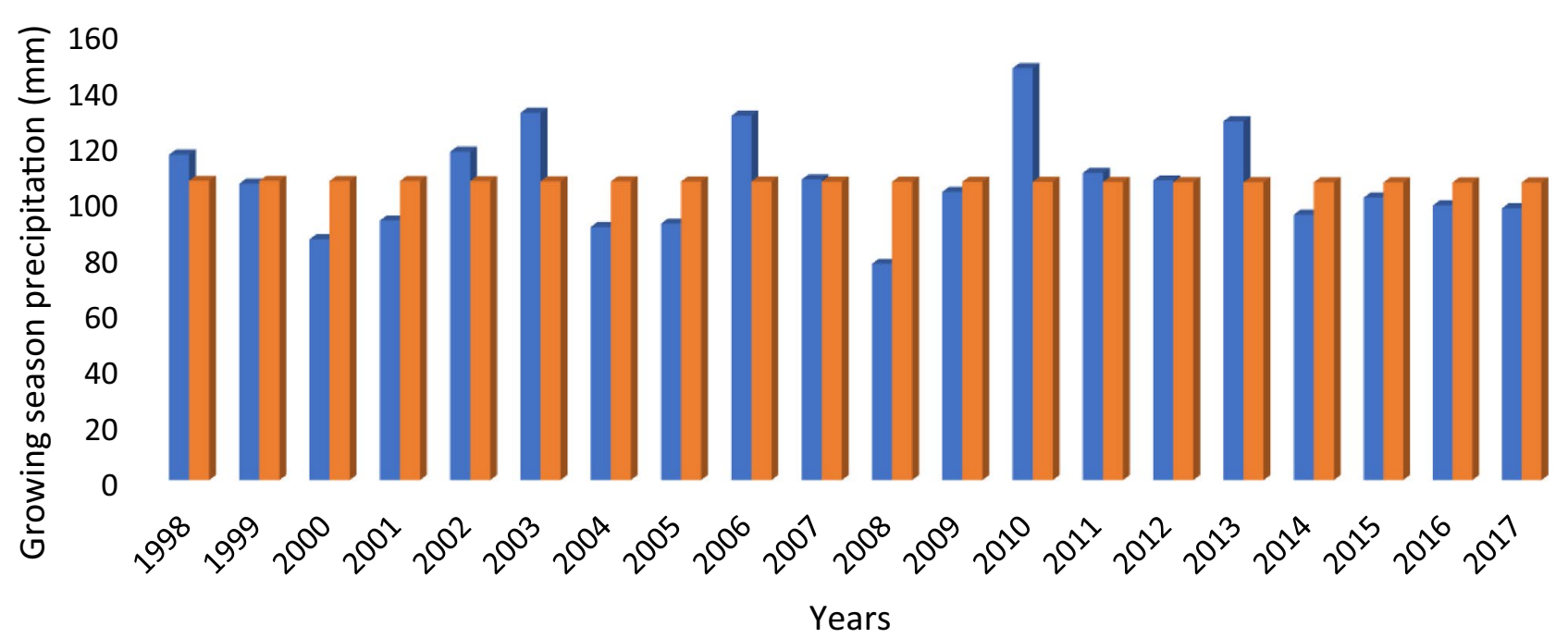

actual obserevd precipitation $\quad$ Projected precipitation

Fig. 6 Actual and projected maize growing season precipitation in Uganda
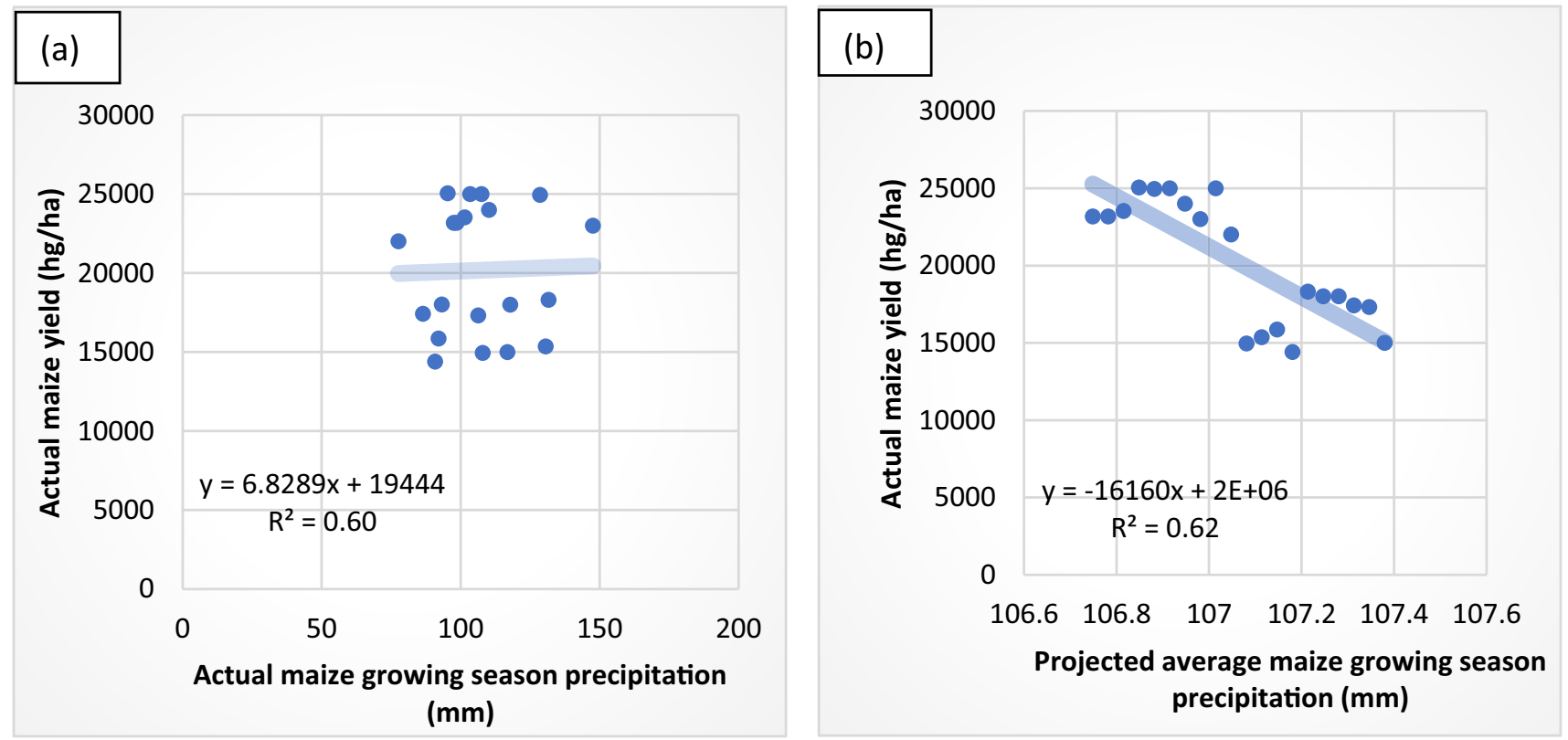

Fig. 7 Scatter plots of a actual growing season precipitation against actual maize yield and $\mathbf{b}$ projected growing season precipitation and actual maize yield

necrosis and fall army worm (a new disease and pest) [1, 27, 32]. These pests and diseases outbreak also caused significant maize yield gaps.

Socio-economic differences in Uganda can also explain the existing maize yield gaps. Generally, crop yield gap differences are often evident between the north and the south of Uganda due to socio-economic disparities. In
2010 , the poverty rate in northern Uganda was $46.2 \%$ and it was higher than the $21.8 \%$ recorded in southern Uganda [12]. Poorer farming communities have less access to farm inputs such as fertilizers, high yielding drought resistant maize varieties, and irrigation infrastructure [4]. Literacy rates also vary between southern and northern Uganda. For example, in 2010, literacy rates in southern Uganda 
were between 63 and $75 \%$ while in northern Uganda they ranged between 60 and 63\% [63]. Small-scale farmers in northern Uganda lack access to adequate transportation in the context of good roads to transport their farm outputs from their farms to markets. They also do not have sufficient access to fertilizers and high yielding maize varieties [30]. When precipitation-based yield gaps occur, the absence of these socio-economic variables makes it impossible or difficult for the farmers to adjust and invest in farm inputs and irrigation related mechanisms that can improve resilience.

The role of socio-economic disparities in maize yield gaps is not an issue that is peculiar to Uganda only. The degree of socio-economic development; assets, whether financial, human, natural, physical, and social do greatly affect the ability of a community to cope with climate change related problems and effects such as yield gaps across Africa $[4,23,43,56]$. Socially, it has been argued that in the face of crop yield gaps, well connected households rely on their friends and families for sustenance and support to reverse yield gaps [50]. In high income countries, social safety nets are so strong that during hazards, shelter, food, clothing and even finances are provided. Also, some farmers are more likely to adjust through some other external inputs such as irrigation water to combat yield gaps. Unfortunately, most countries in Africa do not have access adequate access to this. Things are worse as most of the production is in the hands of small-scale peasant farmers. $[2,3,55]$.

\section{Conclusion}

The results from this study have shown that three key periods of maize yield gaps were recorded between 1998 and 2017. Some of these yield gaps were essentially explained by parallel gaps in precipitation. However, maize yield gaps cannot be always explained by gaps in precipitation. In Uganda as well as in other African countries, soil quality related factors as well as socio-economic disparities such as poverty and literacy have a role to play. Therefore, this study validates the hypothesis that maize yield gaps are a function of precipitation gaps. This validation is however to a certain extent as in some cases maize yield surpluses have been observed to be associated to precipitation gaps. This heralds the argument that, food systems are not just impacted by climatic variables alone but increasingly non-climatic variables. Stakeholders in Uganda and Africa in general must invest in climate science, soil related science, farm inputs, high yielding varieties, crop pests and diseases and in bridging socio-economic gaps through poverty alleviation programs. Going forward, it will be important to verify how these gaps play out in the context of other major crops in Uganda and across Africa and to accurately test the role of climatic and non-climatic variables in crop production systems.

Acknowledgements We want to thank all the authors whom we have cited as well as the FAO and the World Bank Group for sharing most of the time series crop yield and climate data used in this study.

Authors' contributions TEE conceived and designed this study, collected the data, performed the analysis, and wrote the paper. DD, DE, PC, and LL discussed the concept, corrected the methodology and edited the final paper.

Funding This work is supported by a three-year grant of 5 million Moroccan Dirham from UM6P awarded to the corresponding author (Dr. Epule) for newly hired professors at the International Water Research Institute.

Availability of data and materials Data available on request.

Code availability Not applicable.

Declarations

Conflict of interest The authors declare that there are no conflicts of interest.

Consent to participate Not applicable. No human subjects were used in this research.

Consent for publication Not applicable. This study has not used materials from any previously published work.

Ethics approval Not applicable. All the data were culled from online data repositories.

Open Access This article is licensed under a Creative Commons Attribution 4.0 International License, which permits use, sharing, adaptation, distribution and reproduction in any medium or format, as long as you give appropriate credit to the original author(s) and the source, provide a link to the Creative Commons licence, and indicate if changes were made. The images or other third party material in this article are included in the article's Creative Commons licence, unless indicated otherwise in a credit line to the material. If material is not included in the article's Creative Commons licence and your intended use is not permitted by statutory regulation or exceeds the permitted use, you will need to obtain permission directly from the copyright holder. To view a copy of this licence, visit http://creativecommons. org/licenses/by/4.0/. 


\section{References}

1. Asea G, Bigirwa G, Adipala E, Owera SAP, Pratt RC, Lipps PE (2002) Effect of Cercospora zeae-maydis infested maize residue on progress and spread of grey leaf spot of maize in central Uganda. Ann Appl Biol 140(2):177-185

2. Adger WN, Brooks N, Bentham G, Agnew M, Eriksen S (2004) New indicators of vulnerability and adaptive capacity in Technical Report, 7. Tyndall Centre for Climate Research, Norwich

3. Alkire S, Santos ME (2010) Acute multidimensional poverty: a new index for developing countries. OPHI Working Paper No. 38. Oxford Poverty and Human Development Initiative, Oxford

4. Benson T, Chamberlin J, Rhinehart I (2005) An investigation of the spatial determinants of the local prevalence of poverty in rural Malawi. Food Policy 30(5-6):532-550

5. Bindraban PS, van der Velde $M, Y e L$, van den Berg $M$, Materechera S, Kiba DI, Tamene L, Ragnarsdóttir KV et al (2012) Assessing the impact of soil degradation on food production. Curr Opin Environ Sustain 4:1-11

6. Bruinsma J (2009) The resource outlook to 2050. In: Expert Meeting on "How to feed the world in 2050". Rome, Italy 24-26 June 2009. FAO, Rome. http://www.fao.org/3/a-ak971e.pdf. Accessed 16 Nov 2020

7. Cassman KG, Dobermann A, Walters DT, Yang H (2003) Meeting cereal demand while protecting natural resources and improving environmental quality. Annu Rev Environ Resour 28:315-358

8. Challinor A, Simelton ES, Fraser ED, Hemming D (2010) Increased crop failure due to climate change. Assessing adaptation options using models and socio-economic data for wheat in China. Environ Res Lett 5:034012

9. Challinor A, Wheeler T, Garforth C, Kassam A (2008) Assessing the vulnerability of food crop systems in Africa to climate change. Clim Change 83(3):382-399

10. Cooper P, Dimes J, Rao K, Shapiro B, Shiferaw B, Twomlow S (2008) Coping better with current climatic variability in the rain-fed farming systems of sub-Saharan Africa: an essential first step in adapting to future climate change? Agric Ecosyst Environ 126(1):24-35

11. Comenetz J, Caviedes C (2002) Climate variability, political crises, and historical population displacements in Ethiopia. Glob Environ Change B Environ Hazards 4(4):113-127

12. Daniels $L$ (2011) Measuring poverty trends in Uganda with nonmonetary indicators. http://www.fao.org/fileadmin/templates/ ess/pages/rural/wye_city_group/2011/documents/session3/ Daniels___Paper.pdf. Accessed 9 Nov 2020

13. Department of Disaster Management, Office of the Prime Minister (2012) The 2010-2011 integrated rainfall variability impacts, needs assessment and drought risk management strategy. Office of Prime Minster of Uganda. http://gfdrr.org/sites/gfdrr/ files/UGANDA_PDNA_Report_2012.pdf. Accessed 16 Nov 2020

14. Dubois $O$ (2011) The state of the world's land and water resources for food and agriculture: managing systems at risk. FAO, Rome. http://www.fao.org/3/i1688e/i1688e00.pdf. Accessed 16 Nov 2020

15. Epule TE, Bryant CR (2015) Maize production responsiveness to land use change and climate trends in Cameroon. Sustainability 7:384-397. https://doi.org/10.3390/su7010384

16. Epule TE, Bryant CR, Akkari C, Daouda O (2015) Can organic fertilizers set the pace for a greener arable agricultural revolution in Africa? Analysis, synthesis and way forward. Land Use Policy. https://doi.org/10.1016/j.landusepol.2015.01.033

17. Food and Agricultural Organization of the United Nations Statistics Division, FAO (2020) FAOSTAT. http://faostat3.fao.org/ download/Q/QC/E. Accessed 5 Aug 2020
18. Food and Agricultural Organization of the United Nations, FAO (2020) Uganda crop calendar (major crops). http://www.fao. org/giews/countrybrief/country.jsp?code=UGA. Accessed 5 Aug 2020

19. Ford JD, McDowell G, Shirley J, Siewierski PM, R, Gough W, Statham S, (2013) The dynamic multiscale nature of climate change vulnerability: an Inuit harvesting example. Ann Ass Am Geog 103(5):1193-1211

20. Ford JD, Gough WA, Laidler GJ, MacDonald J, Irngaut C, Qrunnut K (2009) Sea ice, climate change, and community vulnerability in northern Foxe Basin, Canada. Clim Res 38(2):137-154

21. Fraser EDG (2006) Agro-ecosystem vulnerability: using past famines to help understand how food systems may adapt to climate change. J Ecol Complex 3(4):328-335

22. Fraser E (2003) Social vulnerability and ecological fragility: building bridges between social and natural sciences using the Irish potato famine as a case study. Conserv Ecol 7(1):9

23. Gbetibouo G, Ringler C, Hassan R (2010) Vulnerability of the South African farming sector to climate change and variability: an indicator approach. Nat Res Forum 34:175-187

24. Global Yield Gap Atlas, GYGA (2013) FAO crop calendars for maize, sorghum, millet, rice and barley. http://www.yieldgap. org/gygamaps/pdf/Details\%20on\%20crop\%20information\% 20to\%20calibrate $\% 20$ crop $\% 20$ models\%20for\%20Uganda.pdf. Accessed 20 May 2020

25. Giannini A, Biasutti M, Held IM, Sobel AH (2008) A global perspective on African climate. Clim Change 90:359-383. https:// doi.org/10.1007/s10584-008-9396-y

26. Green R (1993) The political economy of drought in Southern Africa 1991-1993. Health Policy Plan 8(3):256-266

27. Hailu G, Niassy S, Zeyaur KR, Ochatum N, Subramanian S (2018) Maize-legume intercropping and push-pull for management of fall armyworm, stemborers, and striga in Uganda. Agron J 110(6):2513-2522

28. Held IM, Delworth TL, Lu J, Knutson T, Findell K (2005) Simulations of Sahel drought in the 20th and 21 st centuries. PNAS 102(50):17891-17896. https://doi.org/10.1073/pnas.05090 57102

29. Herrmann SM, Anyamba A, Tucker CJ (2005) Recent trends in vegetation dynamics in the African Sahel and their relationship to climate. Glob Environ Chang 15:394-404

30. IFAD (2012) Enabling poor rural people to overcome poverty in Uganda: rural poverty in Uganda. Rome, Italy. www.ifad.org. Accessed 13 Nov 2020

31. IPCC (2014). In: Barros VR, Field CB, Dokken DJ, Mastrandrea MD, Mach KJ, Bilir TE, Chatterjee M, Ebi KL, Estrada YO, Genova RC, Girma B, Kissel ES, Levy AN, MacCracken S, Mastrandrea PR, White LL (eds) Climate change 2014: impacts, adaptation, and vulnerability. Contribution of working group II to the fifth assessment report of the intergovernmental panel on climate change. Cambridge University Press, Cambridge

32. Kagoda F, Gidoi R, Isabirye BE (2016) Status of maize lethal necrosis in eastern Uganda. Afr J Agric Res 11(8):652-660

33. Kaizzi K (2016) Global yield gap atlas: Uganda. http://www.yield gap.org/gygamaps/excel/GygaUganda.xlsx. Accessed 13 Nov 2020

34. Kaizzi K (2014) Application of the GYGA approach to Uganda. Uganda. http://www.yieldgap.org/gygamaps/excel/GygaU ganda.xlsx. Accessed 13 Nov 2020

35. Larson DF, Savastano S, Murray S, Palacios-López A (2016) On the determinants of low productivity in maize farming in Uganda: the role of markets, fertilizer use and gender. In: In pursuit of an African green revolution Springer, Tokyo, pp 165-182

36. Lobell DB, Schlenker W, Costa-Roberts J (2011) Climate trends and global crop production since 1980. Science 333(6042):616-620 
37. Lobell DB, Cahill K, Field CB (2007) Historical effects of temperature and precipitation on California crop yield. Clim Change 81:187-203

38. Lobell DB, Field C (2007) Global scale climate-crop yield relationships and the impacts of recent warming. Environ Res Lett 2:014002

39. Nelson DR, Adger N, Brown K (2007) Adaptation to environmental change: contributions of a resilience framework. Annu Rev Environ Res 32:395-419

40. Ministry of Agriculture Animal Industry and Fisheries, MAAIF (2019) Maize training manual for extension workers in Uganda. https://www.agriculture.go.ug/wp-content/uploads/2019/09/ Maize-training-manual-for-extension-workers-in-Uganda.pdf. Accessed 12 Nov 2020

41. Mishra AK, Singh V (2010) A review of drought concepts. J Hydrol 391:202-216. https://doi.org/10.1016/j.jhydrol.2010.07. 012

42. Mishra AK, Singh V (2011) Drought modeling - a review. J Hydrol 403:157-175. https://doi.org/10.1016/j.jhydrol.2011.03.049

43. Moser CON (1998) The asset vulnerability framework: reassessing urban poverty reduction strategies. World Dev 26(1):1-19

44. Mugisha J, Sebatta C, Mausch K, Ahikiriza E, Kalule Okello D, Njuguna EM (2019) Bridging the gap: decomposing sources of gender yield gaps in Uganda groundnut production. Gender Technol Dev 23(1):19-35

45. Müller C, Cramer W, Hare WL, Lotze-Campen H (2011) Climate change risks for African agriculture. Proc Natl Acad Sci 108(11):4313-4315

46. Mutai CC, Ward MN (2000) East African rainfall and the tropical circulation/convection on intra-seasonal to inter-annual timescales. Am Meteorol Soc 3:3915-3939

47. Nkonya E, Kaizzi C, Pender J (2005) Determinants of nutrient balances in a maize farming system in eastern Uganda. Agric Syst 85(2):155-182

48. Parry ML, Rosenzweig C, Iglesias A, Livermore M, Fischer G (2004) Effects of climate change on global food production under SRES emissions and socio-economic scenarios. Glob Environ Change 14(1):53-67

49. Poate CD (1988) A review of methods for measuring crop production from small-holder producers. Exp Agric 24:1-14

50. Pretty J (2003) Social capital and the collective management of resources. Science 302:1912-1914

51. Sasson A (2012) Food security for Africa: an urgent global challenge. Agric Food Secur 1:1-16

52. Sacks WJ, Deryng D, Foley JA, Ramankutty N (2010) Crop planting dates: an analysis of global patterns. Global Ecol Biogeogr 19:607-620. https://doi.org/10.1111/j.1466-8238.2010.00551.x
53. Sanchez PA (2002) Soil fertility and hunger in Africa. Science 295:2019-2020

54. Schlenker W, Lobell DB (2010) Robust negative impacts of climate change African agriculture. Environ Res Lett 5:014010

55. Scoones I (1998) Sustainable rural livelihoods: A framework for analysis in working paper, 72. Institute for Development Studies, UK

56. Sen AK (1981) Poverty and famines: an essay on entitlement and deprivation. Clarendon Press, Oxford

57. Senthilkumar K, Rodenburg J, Dieng I, Vandamme E, Sillo FS, Johnson JM et al (2020) Quantifying rice yield gaps and their causes in Eastern and Southern Africa. J Agron Crop Sci 206(4):478-490

58. Shi W, Tao F (2014) Vulnerability of maize yield to climate change and variability during 1961-2010. Food Secur. https://doi.org/ 10.1007/s12571-014-0370-4

59. Simelton E, Fraser EDG, Termansen M, Foster PM, Dougill AJ (2009) Typologies of crop-drought vulnerability: an empirical analysis of the socioeconomic factors that influence the sensitivity and resilience to drought of three major food crops in China (1961-2001). Environ Sci and Policy 12(4):438-452

60. Sserunkuuma D (2005) The adoption and impact of improved maize and land management technologies in Uganda. eJADE Electron J Agric Dev Econ 2(853-2016-56118):67-84

61. Thomson H, Berrang-Ford L, Ford JD (2010) Climate change and food security in Sub-Saharan Africa: a systematic literature review. Sustainability 2:2719-2733

62. Thornton PK, Jones PK, Ericksen PJ, Challinor AJ (2011) Agriculture and food systems in sub-Saharan Africa in a 4 C? World. Philos Trans R Soc A Math Phys Eng Sci 369:117-136

63. Uganda Bureau of Statistics, UBOS (2006) 2002 Uganda population and household census analytical report: education and literacy. http://www.ubos.org/onlinefiles/uploads/ubos/pdf\% 20documents/2002\%20CensusEducAnalyticalReport.pdf. Accessed Nov 2020

64. Wang N, Jassogne L, van Asten PJ, Mukasa D, Wanyama I, Kagezi G, Giller KE (2015) Evaluating coffee yield gaps and important biotic, abiotic, and management factors limiting coffee production in Uganda. Eur J Agron 63:1-11

65. World Bank Group (2020) Climate change knowledge portal for development practitioners and policy makers. http://sdwebx. worldbank.org/climateportal/index.cfm?page=country_histo rical_climate\&ThisRegion=Africa\&ThisCCode=UGA. Accessed 2 May 2020

Publisher's Note Springer Nature remains neutral with regard to jurisdictional claims in published maps and institutional affiliations. 